\title{
Selecting Innovative Approaches to Teaching English to Law Students Via Questionnaire Analysis
}

\author{
Liudmyla Balykina-Halanets $1^{*}$ [0000-0002-2619-1912], Ivan Balykin 2 [0000-0001-6537-559X] \\ ${ }^{1}$ «KROK» University, Kyiv, Ukraine \\ ${ }^{2}$ European University, Kyiv, Ukraine \\ *ludmilai@krok.edu.ua
}

\begin{abstract}
English in Ukraine is one of the integral parts of the training of future lawyers, but there is a problem in accordance with the knowledge of the language by graduates. To solve the problem, in 2018-2019 the authors conducted a survey at five universities of Ukraine (Ivano-Frankivsk Institute of Law of the NU "OLA", National University of Ostroh Academy, «KROK» University, Cherkasy Bohdan Khmelnytsky National University, V. N. Karazin Kharkiv National University). The survey revealed students' expectations of learning English at university, their desire to improve their teaching, and the current level of language proficiency of undergraduate students. The results of the survey became the basis for the study. According to the results of the survey, the article summarizes and formulates recommendations for improving English language teaching methods for law students.
\end{abstract}

Keywords: English for professional purposes, legal English, teaching English at the university.

\section{INTRODUCTION}

Due to globalization processes and the current need for communication between states, there is a requirement for knowledge of a foreign language. This is important for professionals in any field, including lawyers. This primarily applies to the English language. Including, for passing the Unified entrance examination (UEE) (Єдиний вступний іспит $(\mathrm{CBI}))$, which is a condition for admission to the master's degree. For example, in 2019, almost $55 \%$ of bachelors failed to pass the "passed/failed" threshold when entering the legal master's program (Lukans'ka, 2019) [1], and in 2020 $36 \%$ (Ukrainian Center for Educational Assessment Research, 2020) [2]. At the same time, the Ministry of Education and Science of Ukraine has developed and approved the Concept of English Language Development in Universities (Ukraine. Ministry of Education and Science of Ukraine, 2019) [3], intending to develop and apply English in higher education. Besides, the Concept for the Development of Legal Education stipulates that educational programs for the training of lawyers should provide for in-depth study of foreign languages, in particular the official languages of the Council of Europe. (Ukraine. Ministry of Education and Science of Ukraine, 2020) [4] In connection with the above, this topic is relevant. And the question arises how to teach law students English, and what ways to learn the language will be most effective?

\subsection{Study Aims}

The aims of the study are as follows: 1) to analyze the results of the survey in the universities of Ukraine; 2) based on the analysis to formulate practical proposals for methods of teaching English to lawyers in universities.

The article suggests that intercultural communication, digital technology, the Internet, and narrow English for lawyers can add the great potential for language teaching and learning. Of course, teachers and students must know and have the latest technology to implement these changes in teaching and learning the language.

\section{LITERATURE REVIEW}

Scholars around the world raise the problem of teaching English and suggestions for improving the modern approach to teaching. Today processes of globalization encourage intercultural communication in the professional sphere in the first place. Therefore, the correct use of terminology is a determining aspect of the specialist's success and understanding between colleagues. Jia-Fen $\mathrm{Wu}$ (2016) draws attention to this. [5]. It is undeniable that one of the most important elements of the professional competence of future 
lawyers is the proficiency in a foreign language at a level accessible to the recipient. That is why learning a foreign language as a means of communication in the process of future professional activity is a priority of the teacher, as noted by Tymoschuk and Dovgan' (2013) [6], Hu (2019) [7], Yankova (2017) [8], Giampieri (2017) [9]. In addition to vocabulary, pronunciation is important, and Arai and Oda (2015) [10] suggest using voice (audio) and computer animation to improve it.

Foreign colleagues in the process of teaching English are already implementing and effectively using digital technologies and tools of online education, as evidenced by numerous studies. Heping, Jinchuan, Rongping, Zhenli (2013) [11], Chovancov'a (2016) [12] point out that multimedia and online teaching are an effective way to improve English language teaching and learning. In Ukraine, there was widespread talk about the effectiveness of these tools in the learning process only when in March 2020 universities due to COVID quarantine were forced to switch to online teaching. Ling, Kai (2012) [13], Zakarneh (2017) [14], Kerimbaeva, Niyazova, Kaya (2017) [15] emphasize the need for teachers to use computers and the Internet in the process of teaching English, which can cause great changes in teaching concepts, teaching models, methods and teaching aids, as well as in the expanded range of teaching and learning materials. At the same time, modern digital teaching methods have already been created and tested in foreign countries, namely Teaching Assisted Language Learning (TALL), Technology Enhanced Language Learning (TELL), Computer Assisted Language Learning (CALL), Web Enhanced Language Learning (WELL), and Mobile Assisted Language Learning (MALL), which Kumar and Sailaja analyze in their study (2015) [16]. Therefore, Ukrainian universities and teachers have only to choose a method that is acceptable to them.

Despite of numerous studies on the English language and tools that increase the effectiveness of teaching and learning, there is no comprehensive analysis of the situation among law students in Ukraine. The authors of the article conducted a survey at five universities in different cities of Ukraine (Kyiv, Ivano-Frankivsk, Cherkasy, Ostroh in Rivne Oblast, Kharkiv) to find new approaches to solving the problem of improving the level of English language skills of future domestic specialists.

\section{ANALYSIS OF THE NECESSITY OF ENGLISH TO LAW-STUDENTS}

Let's focus on the fact that in Ukraine, knowledge of English is required for admission to graduate school. From 2016, all bachelor students who want to enter a law degree must pass a single professional entrance examination (SPEE) (Сдине фахове вступне випробування (СФВВ)) and a Unified entrance examination (UEE) in a foreign language. (Ukraine.
Cabinet of Ministers of Ukraine, 2016) [17] Another language can be chosen instead of English. In 2020, it was possible to compile a UEE in English, German, French and Spanish. English is compulsory for studying in high school and higher education institutions, so most entrants choose it. In this regard, universities have changed curricula. Thus, before this testing in most institutions English language for lawyers was taught exclusively in the 1 st and 2 nd courses, and now - all four years of bachelor's degree. In the master's degree, language learning continues. Consequently, English for lawyers in Ukraine represents a special value not only if the specialist wants to start a career abroad, get a promotion in a foreign company or recognition of the world's leading associations of lawyers, as well as if there is a desire to do research, teaching, government work, and there is a need to enter the master's degree. For a master's degree, the need for knowledge of English is indisputable not only for maintaining international scientific contacts but also for writing an abstract in the preparation of a particular scientific work. This requirement is mandatory for publication in any professional edition.

Many courses promise to increase English knowledge and train a competitive specialist. For example, the online course of legal English was among the five most popular among law students, as the analysis of Baczynski and Shpilka (2019) shows [4].

The paid courses tell about the peculiarities of legal English and offer their solutions and ways to learn this difficult language. Therefore, students have questions about the quality of higher education provided. And in universities, there is a question of survival in the market of educational services, especially during the global pandemic, when everyone was forced to switch to online education and actively use the latest technologies for the implementation of the educational process. In this article we raise the question of the possibility of universities training a highly qualified specialist, and what is needed for this?

The issue of reforming higher legal education is relevant. The debate on reform has not abated. One of the points of which is the issue of language training of future lawyers. Learning a foreign language at a sufficient level is a necessity for a lawyer. Since 2014, the reform of legal education in Ukraine has been considered an integral part of the systemic legal reform.

\section{METHODOLOGY}

\subsection{Profile of respondents}

The article analyzes the data obtained as a result of a survey that took place in 2018-2019. The survey involved 500 undergraduate students of law faculties, 100 from each university. Namely, in Ivano-Frankivsk Institute of Law of the NU "OLA", National University of Ostroh 
Academy, «KROK» University, Cherkasy Bohdan Khmelnytsky National University, V. N. Karazin Kharkiv National University. Students from the 1st to 4th year were selected. All answers were used.

\subsection{The Questionnaire}

7 questions were asked in the questionnaire.

1. Do you consider it necessary for a lawyer to speak English at a high professional level? (select one of the answers)

$$
\text { Yes No }
$$

2. Would you like to study English for lawyers with a narrower specialization at the university? (select one of the answers)

$$
\text { Yes No }
$$

3. If the answer is "yes" to the previous question, indicate which professions you are interested in learning in more detail in English? (Example: counselor, notary, judge, etc.)

Your option

4. What is the easiest way for you to learn English:

- $\quad$ listening;

- $\quad$ visual study (online communication, recorded programs, movies);

- $\quad$ studying of material from a specially prepared textbook;

- $\quad$ studying of material from an interactive medium on a computer;

- live communication with specialists;

5. What level of English language do you have? (select one of the answers)

- $\quad A-$ Basic User:

- Al - Survival Level - Beginner and Elementary

- $\quad$ A2 - Waystage-Pre-Intermediate

- $\quad B-$ Independent User:

- $\quad$ B1-Threshold-Intermediate

- $\quad B 2$ - Vantage - Upper-Intermediate

- $\quad C$-Proficient User:

- $\quad C 1$ - Effective Operational Proficiency Advanced)

- $\quad$ C2 - Mastery - Proficiency

6. Do you have a document confirming your level of English proficiency? (select one of the answers)
Yes

No

7. If the answer is "yes" to the previous question, specify which document you have:

(select one of the answers)

- $\quad$ diploma of the school with in-depth study of English;

- certificate.

In questions $1,2,5,6,7$, respondents had to choose one answer from the suggested ones. In question 3 - write your answer (someone mentioned one, and someone several), and in question 4 - several of the proposed could be chosen. Respondents answered all questions. All 500 questionnaires that were used in the analysis were processed. Accordingly, 500 questionnaires are 100\%, $1 \%-5$ questionnaires.

\section{DATA ANALYSIS AND DISCUSSION}

Table 1 present the results of the survey. The results are calculated by the number of responses provided.

We turn to the analysis of the survey results. In Ukraine today, learning English is compulsory from the first grade of school. Modern conditions of intercultural communication necessitate knowledge of the language. However, the first question was formulated as follows to find out if future specialists feel the need to know English. Namely, do you consider it necessary for a lawyer to speak English at a high professional level? The answers provided showed that the attitude to the need for language skills in higher education institutions is similar. Namely, only $10 \%$ believe that there is no need to speak English at a high level, and the remaining $90 \%$ have the opposite opinion. Therefore, we believe that there is an urgent need for our study [18].

The next two questions are interconnected. The second question was «Would you like to study English for lawyers with a narrower specialization at the university». Most respondents from all universities answered in the affirmative. The general picture is as follows: "yes" $-29 \%$, "no" $-71 \%$. This picture leads to the next question, where students had to enter their professions, which they wanted to study in more detail in English. Analyzing the results for all five universities, we see the following. First, it will be recalled that the respondents independently indicated their profession. From the proposed choice, we can first divide the choice into the following groups: national law (counselor - 40\%, judge $-21 \%$, notary $-12 \%$, prosecutor $-8 \%$, investigator $-4 \%$, lawyer $-3 \%$, police officer - $2 \%$, mediator $-0 \%$, customs officer - $0 \%$, Security Service of Ukraine employee - 0\%), and international law (international lawyer $-7 \%$, diplomat $-1 \%$, ambassador - $1 \%$, consul $1 \%)$. 
Table 1. Survey results

\begin{tabular}{|c|c|c|c|c|c|c|}
\hline Столбен & $1^{1}$ & $2^{2}$ & $3^{3}$ & $4^{4}$ & $5^{5}$ & $\stackrel{\ominus}{\Xi}$ \\
\hline TOTAL students who took part in the survey & 100 & 100 & 100 & 100 & 100 & 500 \\
\hline \multicolumn{7}{|c|}{ 1. Do you consider it necessary for a lawyer to speak English at a high professional level? } \\
\hline Yes & 95 & 82 & 93 & 91 & 89 & 450 \\
\hline No & 5 & 18 & 7 & 9 & 11 & 50 \\
\hline \multicolumn{7}{|c|}{ 2. Would you like to study English for lawyers with a narrower specialization at the university? } \\
\hline Yes & 78 & 56 & 80 & 71 & 72 & 357 \\
\hline No & 22 & 44 & 20 & 29 & 28 & 143 \\
\hline \multicolumn{7}{|c|}{$\begin{array}{l}\text { 3. If the answer is "yes" to the previous question, indicate which professions you are interested in learning in } \\
\text { more detail in English? (Example: counselor, notary, judge, etc.) }\end{array}$} \\
\hline counselor & 35 & 31 & 60 & 47 & 30 & 203 \\
\hline judge & 23 & 24 & 22 & 25 & 15 & 109 \\
\hline notary & 12 & 14 & 15 & 15 & 8 & 64 \\
\hline prosecutor & 6 & 7 & 5 & 16 & 5 & 39 \\
\hline lawyer & 5 & 3 & 1 & 6 & 0 & 15 \\
\hline mediator & 1 & 0 & 0 & 0 & 0 & 1 \\
\hline diplomat & 6 & 1 & 0 & 0 & 0 & 7 \\
\hline ambassador & 3 & 0 & 0 & 0 & 0 & 3 \\
\hline consul & 3 & 0 & 0 & 0 & 0 & 3 \\
\hline international lawyer & 4 & 1 & 27 & 0 & 3 & 35 \\
\hline investigator & 7 & 2 & 0 & 6 & 4 & 19 \\
\hline police officer & 0 & 1 & 4 & 4 & 0 & 9 \\
\hline customs officer & 1 & 0 & 0 & 0 & 0 & 1 \\
\hline Security Service of Ukraine employee & 0 & 0 & 1 & 0 & 0 & 1 \\
\hline \multicolumn{7}{|c|}{ 4. What is the easiest way for you to learn English: } \\
\hline listening & 11 & 12 & 8 & 12 & 18 & 61 \\
\hline visual study (online communication, recorded programs, movies) & 28 & 38 & 43 & 47 & 27 & 183 \\
\hline studying of material from a specially prepared textbook & 38 & 23 & 39 & 26 & 38 & 164 \\
\hline studying of material from an interactive medium on a computer & 9 & 7 & 14 & 14 & 7 & 51 \\
\hline live communication with specialists & 57 & 37 & 66 & 13 & 65 & 238 \\
\hline \multicolumn{7}{|c|}{ 5. What level of English language do you have? } \\
\hline A & 5 & 16 & 6 & 27 & 18 & 72 \\
\hline A1 & 5 & 24 & 23 & 21 & 24 & 97 \\
\hline A2 & 13 & 20 & 15 & 10 & 25 & 83 \\
\hline B & 12 & 14 & 13 & 14 & 8 & 61 \\
\hline B1 & 36 & 14 & 14 & 17 & 15 & 96 \\
\hline B2 & 27 & 5 & 26 & 11 & 6 & 75 \\
\hline $\mathrm{C}$ & 1 & 3 & 2 & 0 & 1 & 7 \\
\hline $\mathrm{C} 1$ & 1 & 2 & 0 & 1 & 0 & 4 \\
\hline $\mathrm{C} 2$ & 0 & 0 & 0 & 0 & 0 & 0 \\
\hline \multicolumn{7}{|c|}{ 6. Do you have a document confirming your level of English proficiency? } \\
\hline Yes & 13 & 14 & 6 & 7 & 10 & 50 \\
\hline No & 87 & 86 & 94 & 93 & 90 & 450 \\
\hline \multicolumn{7}{|c|}{ 7. If the answer is "yes" to the previous question, specify which document you have: } \\
\hline Diploma of the school with in-depth study of English & 3 & 5 & 3 & 2 & 5 & 18 \\
\hline Certificate & 10 & 9 & 4 & 4 & 5 & 32 \\
\hline
\end{tabular}

These groups are conditional. The purpose of this question was to find out what specializations students are interested in, namely judicial work (counselor, judge, prosecutor, mediator), contract (notary, lawyer), practice in government agencies (investigator, police officer, customs officer, Security Service of Ukraine employee, diplomat, ambassador, consul) and corporate practice (international lawyer). Therefore, there is a recommendation - instead of teaching legal English in general, to offer from the 3rd year English with narrow

\footnotetext{
${ }^{1}$ V. N. Karazin Kharkiv National University

2 Ivano-Frankivsk Institute of Law of the NU "OLA"

${ }^{3}$ National University of Ostroh Academy

${ }^{4}$ Cherkasy Bohdan Khmelnytsky National University

5 «KROK» University
} 
specialization. This will be effective because each specialization requires knowledge of industry legislation, special terminology, and the specifics of the work as a whole. As a result, the graduate will have a better chance of getting a job.

The fourth question is about more favorable ways to learn English for each student. As we can see, according to the results, each University has its preferences. For example, at V. N. Karazin Kharkiv National University, National University of Ostroh Academy and «KROK» University, the majority chose "live communication with specialists", and in Ivano-Frankivsk Institute of Law of the NU "OLA" and Cherkasy Bohdan Khmelnytsky National University is "visual study (online communication, recorded programs, movies)". At the same time, look at the general picture in Figure 1.

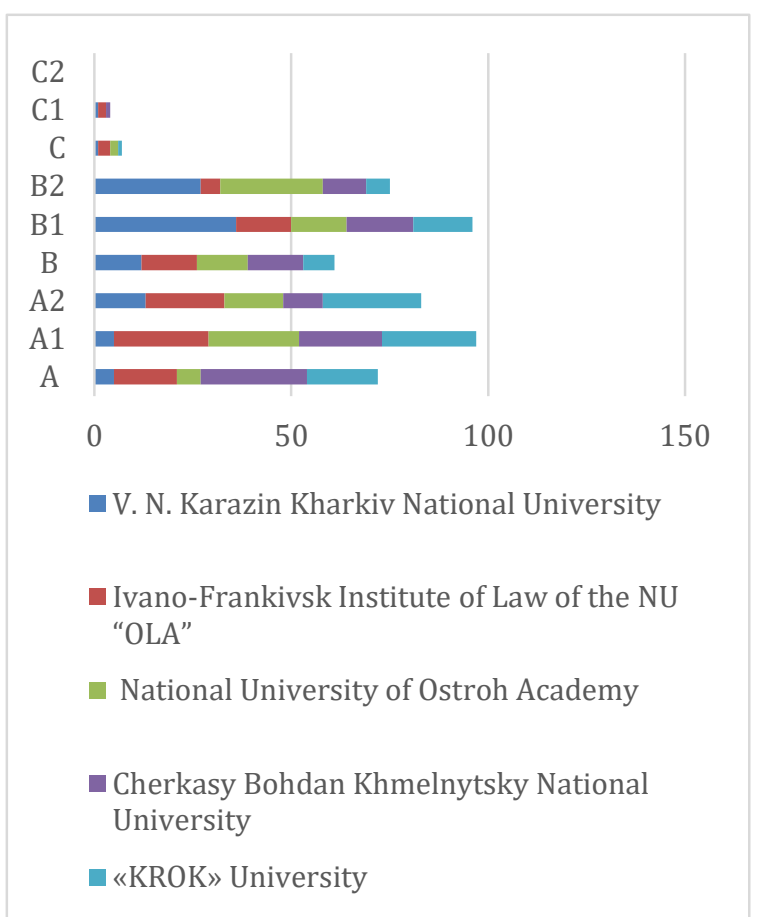

Figure 1 Ways to learn English

Consequently, with a great advantage, the choice of students showed an interest in live communication with specialists, visual study (online communication, recorded programs, films) and the study of material from a specially prepared textbook. This choice suggests that Ukrainian universities should involve digital technologies in the learning process. And the experience of online education during quarantine in connection with the COVID-19 epidemic leads to the development of this form of education, and after leaving quarantine to use their experience and move to blended learning, which combines offline and online formats.

The results of the answers to the next question, where it was necessary to indicate your level of English, showed the following. Note that to study English for lawyers in higher education, you need a level of at least B1
Intermediate. The survey showed that the level of language proficiency varies from university to university. Namely, a greater number of students among 100 chose: at V. N. Karazin Kharkiv National University B1 (36), in Ivano-Frankivsk Institute of Law of the NU "OLA" A1 (24), at National University of Ostroh Academy B2 (26), in Cherkasy Bohdan Khmelnytsky National University A (27), and at «KROK» University A2 (25). See the full picture in Figure 2.

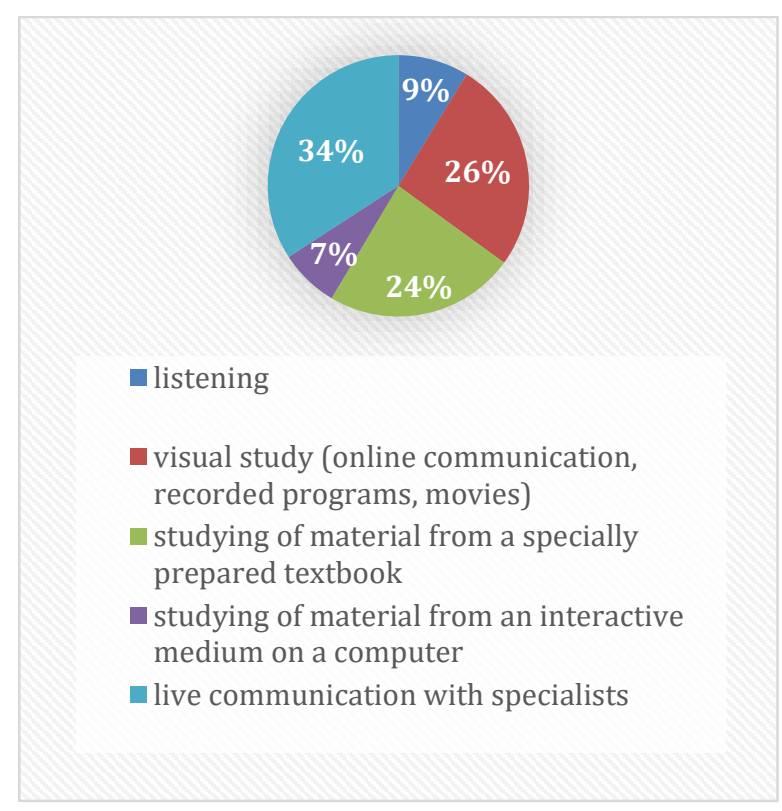

Figure 2 English language proficiency

These indicators show that entrants who entered a higher education institution do not have a sufficient level of knowledge of the language to develop it in a professional direction. And teachers need to start teaching what they need to learn in school. This is one of the reasons why most university graduates cannot find a job in the labor market in modern conditions, due to one of the main requirements - knowledge of English, so this is emphasized in the process of reforming legal education. It is necessary to get basic knowledge at school to hone them in universities. Accordingly, it is necessary to make restrictions for entrants during the entrance to a higher education institution, so that only those who have a level of knowledge not lower than B1, to pass the UEE not lower than B2. This approach to the preparation of external evaluation and UEE is defined in the Concept of English Language Development in Universities. (Ukraine. Ministry of Education and Science of Ukraine, 2019) [3].

The last two questions are related. The authors aimed to find out whether the respondents have documents proving their knowledge of the language, and if so, which ones. The survey showed that only $10 \%$ of students who took part in the survey have a document. Namely, a school diploma with in-depth study of English - 18, and a certificate -32 . These results suggest that the real 
picture of the level of knowledge of English may be worse.

\section{CONCLUSION}

In conclusion, we would like to note that the purpose of any professional education is to achieve a high level of professional competence for future professionals, including lawyers. If the student has sufficient motivation and opportunities to learn legal English, then, in our opinion, he/she will do everything in his/her power (and even more), and the teacher in the process of learning legal English will be only a guide.

Within the framework of this article, the analysis of the results of the survey in the universities of Ukraine was carried out. And on its basis, the following practical proposals on the methods of teaching English for lawyers in the institutions of higher education were formulated. First, instead of teaching legal English in general, offer 3rd year English with narrow specialization. Second, use digital technology and the Internet in the learning process. Third, to pass the entrance test in such a way that the entrant has the opportunity to enter a higher education institution with a level of English not lower than B1, and a master's degree - not lower than B2.

The practical significance of this analysis is that it can help teachers to improve their knowledge of legal English. Also, the authors hope to guide future research in this area.

\section{ACKNOWLEDGMENTS}

We are especially grateful to Doctor of Laws Frantsuz-Yakovets T., Associate Professor Dolyanovska I., and Candidates of Law Kornienko O., Panchuk I., Slinko D. for their help in surveying in Ukrainian universities.

\section{REFERENCES}

[1] Lukans'ka, A. (2020), "The problem of reforming legal education is nationwide", Voice of Ukraine, available at: http://www.golos.com.ua/article/338258.

[2] Ukrainian Center for Educational Assessment. Report on the conduct of entrance examinations in 2020, conducted using the organizational and technological processes for the implementation of external independent assessment for admission to the second (master's) level of higher education, available at: https://testportal.gov.ua/wpcontent/uploads/2020/12/Zvit-YEFVVYEVI_2020_.pdf .

[3] Ministry of Education and Science of Ukraine. Conceptual principles of state policy on the development of the English language in the field of higher education (2019), available at: https://webcache.googleusercontent.com/search?q
=cache:IoEQwf0Ax74J:https://mon.gov.ua/storage /app/media/2019-06-24-proekt-konts-angl-movi1.docx $+\& \mathrm{~cd}=2 \& \mathrm{hl}=\mathrm{ru} \& \mathrm{ct}=\mathrm{clnk} \& \mathrm{gl}=$ ua.

[4] Ministry of Education and Science of Ukraine. The concept of legal education development, (2020), available at: https://mon.gov.ua/ua/osvita/vishaosvita/koncepciya-vdoskonalennya-pravnichoyiyuridichnoyi-osviti-dlya-fahovoyi-pidgotovkipravnika.

[5] Wu, J.-F. (2016), "Impact of Foreign Language Proficiency and English Uses on Intercultural Sensitivity", Modern Education and Computer Science, №8, pp. 28-35. DOI: 10.5815/ijmecs.2016.08.04.

[6] Tymoschuk, N. M. and Dovhan', L. I. (2013), "Formation of professional qualities of future lawyers in the process of learning foreign languages. Scientific notes", Ser.: Social Sciences and Humanities, issue 2, pp. 190-196.

[7] Hu, W. (2019), "On Legal English Translation from the Perspective of Legal Linguistics", Review of Educational Theory, volume 02, issue 03, pp. 6-10. DOI: $10.30564 /$ ret.v2i3.870.

[8] Yankova, D. (2017), "An attempt at redefining legal English contexts", International Journal of Language Studies, vol. 11, no. 4, pp. 173-191.

[9] Patrizia Giampieri P. (2016), "Is the European Legal English Legalese-Free?", Italian Journal of Public Law, vol. 8, issue 2, pp. 424-440.

[10] Arai, K. and Oda, M. (2015), "English Pronunciation Practice Method with CG Animations Representing Mouth and Tongue Movements", Modern Education and Computer Science, № 7, pp. 1-7. DOI: 10.5815/ijmecs.2015.07.01

[11] Heping, W. Jinchuan, Z. Rongping, F. and Zhenli, S. (2013), "Teaching Non-English-Majored College Students Listening and Speaking Through Multimedia and Network". Education and Management Engineering, №1, pp. 44-48. DOI: 10.5815/ijeme.2013.01.08.

[12] Chovancova, B. (2016), "Mediation in Legal English Teaching", Studies in Logic, Grammar and Rhetoric, № 45 (58). DOI: 10.1515/slgr-20160013.

[13] Ling, J. and Kai, S. (2012), “Application of TaskBased Approach in College English Teaching Based on Internet-assisted Multimedia", Education and Management Engineering, № 8, pp. 58-64. DOI: $10.5815 /$ ijeme.2012.08.10.

[14] Zakarneh, B. M. (2018), "Effectiveness of Elearning Mode for Teaching English Language in 
Arab Universities", International Journal of Applied Linguistics \& English Literature, № 7 (7), pp. 171-181. DOI: 10.7575/aiac.ijalel.v.7n.7p.17.

[15] Kerimbaeva, B. T. Niyazova, G. T. and Kaya, K. (2017), "The Role of Computer Technology in Teaching English Language", RUDN Journal of Informatization of Education, vol. 14, № 1, pp. 108-113. DOI: 10.22363/2312-8631-2017-14-1108-113.

[16] Jeevan Kumar, T. and Sailaja, G. (2015), "The Best Method to Teach English Language", ELK Asia Pacific Journals, Special Issue, DOI: 10.16962/elkapj.

[17] Cabinet of Ministers of Ukraine. On conducting entrance examinations in 2016 as an experiment for admission on the basis of a bachelor's degree to obtain a master's degree in the specialty 081 "Law" using organizational and technological processes of external independent evaluation (2016), available at: https://zakon.rada.gov.ua/laws/show/121-2016$\%$ D1\%80\#Text.

[18] Bachyns'kyj, T. and Shpil'ka, O. (2019), "Development of online education in the legal field. The results of the survey", $A P h D$, available at: http://aphd.ua/tezy-ta-naukovi-statti.

[19] Hassan, M. M., Mirzam T. and Hussain M.W. (2020), "A Critical Review by Teachers on the Online Teaching-Learning during the COVID-19", Education and Management Engineering, № 5, pp. 17-27. DOI: 10.5815/ijeme.2020.05.03. 